\title{
0
}

\section{PALESTINIAN CHILDREN CRAFTING NATIONAL IDENTITY}

\author{
JANETTE HABASHI \\ University of Oklahoma \\ Keywords: \\ children, geopolitical, identity ideology, \\ national, Palestine \\ Mailing address: \\ Janette Habashi \\ Department of Human Relations, \\ University of Oklahoma, Schusterman \\ Center, 4502 East 41st Street, Tulsa, OK \\ 74135, USA. \\ [email: jhabashi@ou.edu] \\ Childhood Copyright (c) 2008 \\ SAGE Publications. Los Angeles, London, \\ New Delhi and Singapore, Vol 15(1): 12-29. \\ www.sagepublications.com \\ $10.1177 / 0907568207086833$
}

This study examines the formulation of national identity in Palestinian children by exploring their understanding of its paradoxes. Twelve Palestinian children were interviewed from cities, villages and refugee camps in the West Bank. The children express the multiple dimensions of national identity in terms of self and other; however these expressions are fragmented in nature. Furthermore, the findings indicate that national identity highlights children as geopolitical agents, rather than separate entities defined by time.

\section{Research statement}

The purpose of this study is to set a platform for analyzing the national identity of Palestinian children in the West Bank. National identity emerges from and responds to geopolitical discourses. Geopolitical identity is not limited to an actual geographical boundary, but is concerned with the conceptualization and meaning of boundaries that are not limited to territorial space (Tuathail and Dalby, 1998). Respectively, national identity mirrors the intersection of the nation's historical development and geopolitical events (Anderson, 1991; Crane, 1996; Said, 1993). Segments of historical narratives and geopolitical discourses are an active component in contemporary national identity (Hutton, 1993; Jennings, 1996; Smith, 1991). Understanding these interactive aspects of children's national identity is the essence of this research. This study examines Palestinian children's rendering of national identity in a warlike situation.

Research on children in war zones is moving away from the depiction of them as vulnerable and traumatized (Feerick and Prinz, 2003), to the examination of children as valuable contributors to society (Cheney, 2005). This assumption aligns with the present study and its analysis whereby it also embraces the notion of children's geopolitical agency. Children's evolution into geopolitical agents is associated with conceptual domains that are in contention with world politics, hegemony and geographical space (Tuathail, 2000). Children as geopolitical agents are the product of power structures and geographic relations in regard to local discourses. Geopolitical agency is generated by children's active experience of the power discourse that goes 
beyond specific territories and its impact on their local social milieux. In this hybrid context, children become agents not only to a territorial state per se, but also to the global hegemony in relation to local politics. Therefore, to understand children's geopolitical agency, first it is critical to study children's conceptualization of national identity.

This research is important on two levels. First of all, there is little academic work associated with the direct voices of Palestinian children living in the West Bank regarding national identity and, although children's images are represented in the Palestinian national identity, the children's depictions of their own identities are not voiced (Assad, 2000). Second, there is a growing interest in the analysis of the complexity of children's national identity in war zones (Bixler, 2005; Cheney, 2005). In this respect, there is a need to explore theoretical approaches to understanding Palestinian children's construction of national identity and the implication for their futures. Traditionally, research on children's national identity focuses on studying its correlation with state doctrine infused in school curricula (Howard and Gill, 2001; Myers, 1999). This approach is irrelevant in the Palestinian case, not because Palestinians have no control of the design of school curricula (Assad, 2000), but because other prevalent aspects such as community activities, intergenerational dialogue and media portrayals contribute to the rendering of Palestinian national identity (Aqtash, 2005; Habashi, 2004). The significance of studying these dispersed aspects is the direct association with geopolitical discourse. This approach perceives national identity as a continuous emerging process rather than a pretext. Endorsing the interactive approach enhances our understanding of children's experiences in constructing their own national identity.

In order to address all the elements pertinent to the analysis of Palestinian children's construction of national identity, this article is divided as follows. The first part introduces the development of Palestinian national identity. The second describes the methodology used in this research. The following sections present the children's narratives and themes. The final section provides a discussion of the data collected and presents a holistic conclusion.

\section{Representations of the Palestinian national identity}

Contemporary Palestinian national identity is at an ambiguous stage because the components of national identity do not currently exist in one particular space or one exclusive geographical sphere. The components of national identity are scattered in the remains of Palestine (the West Bank, the Gaza Strip and the East Jerusalem zone), and include the Palestinian people living in Israel as well as Palestinians in diasporas residing mainly in refugee camps in Jordan, Lebanon, Syria and Egypt. Their evacuation from Palestine was a result of both Al-Nakbah in 1948 when the Zionist army colonized 80 percent of historical Palestine, and the 1967 Six Day War when the Israeli military occupied the 
rest of the Palestinian territories that were under Jordanian and Egyptian control (Carey, 2001; Kapitan, 1997; Pappe, 1992; Smith, 2001). In the 1960s, the Palestinian national identity was publicly expressed through the establishment of the Palestinian Liberation Organization (PLO). The main goal of the PLO was to liberate Palestine. Today, seven political parties constitute the PLO. In the 1980s, Hamas established a political party but did not join the PLO. This diverse political spectrum forecasts both a secular state and religious state for the Palestine of the future (Link, 1996). The parties' ideologies are closely aligned with an expression of national identity, and these are projected in street politics. As a result, Palestinian history demonstrates many expressions of national identity across time. Palestinian national identity developed not only from an interpretation of the historical and contemporary experiences, but also from the proximate existence of the state of Israel that impacted the creation of Palestinian national identity. Indeed, Palestinian national identity is exceedingly complicated, not just because of its history, but also because of its contemporary geopolitical implications. The changing of the geographical borders of Palestine aided in the development of a fragmented national identity (Khalidi, 1997). The core of the Palestinian cause is not the borders or the historical consciousness of the Palestinian people. Instead, it is the creation of a national discourse endorsed by scattered Palestinians living throughout various geopolitical locales (Abu-Lughod, 1993). However, it is insufficient to assume that the emergence of a Palestinian identity was primarily due to the construction of the other, in this case Israel or the Zionists' movement. The emergence of a Palestinian identity was part of the universal notion of nationalism that developed during the 20th century. Most of the countries arising from the devastation of the Second World War developed a nationalistic notion (Khalidi, 1997). Hence, the contemporary Palestinian national identity was developed through acknowledging Israel as an other (Kelman, 1999).

\section{Methodology}

\section{Participants and the context of the study}

Data were collected from interviews with 12 Palestinian children during the fall of 2001. The participants were aged between 10 and 13 years old. Four children were interviewed from three different geographic areas: cities, refugee camps and villages in the West Bank. Also, the study was divided equally across gender. The overarching questions were: How would you define a Palestinian person? Where did you learn about Palestine? What is the history of Palestine? Who is a Palestinian refugee? What do you think about the current political situation and the future? All the interviewees were contacted during the second uprising (Intifada) in the occupied territories in the West Bank and the Gaza Strip. 


\section{Data analysis and emerging themes}

The interview questions were based on an open-ended structure. Interviewees produced rich data that enhance the understanding of the research statement. The grounded theory method guided the development of the study and data analysis. The purpose of grounded theory is to study social phenomena through identifying patterns and relationships; coding facilitates this procedure. Cross-members checking served to verify the analysis by utilizing the comparison of coding between the data across different interviews and within the data produced by each interviewee. The data reveal two main categories, namely, the dimensions of the self and the other. Additionally, the data disclose four subthemes for the other category and six subthemes for the self. The words expressing these main categories are words like 'they', 'Israelis', 'soldiers', 'us', 'martyrs' and 'Palestinian people'. The language contributes to the analysis and facilitates in the naming of the themes, and this naming maintains the integrity of themes while assisting in defining concepts according to participants.

\section{Other}

The other, on many occasions, refers to the Jewish people, the Zionists, the Israeli army and the state of Israel. The participants articulate a fragmented image of the other and these articulations assist in the incorporation of the historical creation and contemporary meaning into national identity. Palestinian children's ability to render the other is paradoxical, and thus divided into four categories: (1) the oppressor other, (2) scattered other, (3) allying other and (4) religious other.

\section{The oppressor other}

The participants construct the oppressor other within the historical development of the other. The understanding of historical discourses facilitates the emerging meaning of the contemporary oppressor. Participants integrated historical experiences within the contemporary national discourse such as the Balfour Declaration, which gave the Zionist movement the right to have a Jewish homeland in Palestine in 1917 without the consent of the Palestinian people at that time (Khalidi, 1997). As one female participant stated, 'It started in 1917. It was the end of the World War I and [the] Balfour Accord was in place. It was an agreement to ease the immigration of Jews from Russia and America and other countries to Palestine.' Engaging historical events in national discourse is a frequent occurrence in the children's discussion and their construction of the oppressor other. Recollection of such events is evidence of the impact of the events of the year 1948 on the collective consciousness and the contemporary political situation. As one male participant indicated, 'Palestinians lived in the land before the Jews took it and called it Israel. In 1948 they displaced the Palestinians from their homes and took the 
land, destroyed homes and they killed some Palestinians.' Anderson (1991) indicates that a particular set of historical memories play a prominent role in the formation of national identity. Indeed, this was the case with participants in this study, but memories are conditional upon the geopolitical discourse. The political discourse of the early 20th century was predominant in the establishment of contemporary Palestinian national identity (Kelman, 1999). Participants in the study possessed the ability to understand historical geopolitical elements such as the British mandate, Jewish suffering and immigration and the impact of these events on the national identity. As one female participant articulated, 'Jewish people from abroad came while Hitler burned them, and they [the world leaders] wanted to solve the problem by creating a homeland for them in Palestine.' This complex view of Palestinian national identity coincides with Tuathail and Dalby's (1998) definition of geopolitical identity, which examines the global discourse and its intersection with local identity.

History did not start during western colonization, but the recollections of those years significantly influence the children's views of the historical rights of Palestinians and Jews in regard to the land. Participants' articulations express the other in complex terms whereby their deliberation of the other presents challenges in naming the oppressor other. Naming the other was an important element in the children's narratives, and revealed nuances in the construction of the oppressor other. Before the Palestinian displacement, in 1948, Israel did not exist; and the other in this period was primarily the people who endorsed the Zionists' views, which orchestrated the establishment of the state of Israel and the displacement of the Palestinians. However, the challenge is that the naming of the other has changed from the Jewish people who endorsed Zionists' views to include the allies of that perspective. As one male participant stated, 'Israelis are our enemy. The enemy is also America.' Said (1993) articulates the impact of colonial discourse on changing the meaning of an event. Therefore, naming the other assisted in its construction and simultaneously provided nuances in contemporary political meaning of the other. Exchanging different names of the oppressor other reflects participants' understanding of time and political discourse. Participants differentiate the timeline and ideology of the establishment of the Israeli state and the Zionist movement in this geopolitical project (Khalidi, 1997); a male interviewee commented:

We the Palestinians have a problem with the Israelis and the Zionists, with the Zionist as Arab people and with the Israelis as Palestinian people. We have a problem with the Israeli people and their government. ... The Israeli people elected the Israeli government; the government is part of the people.

Participants' consideration of the global geopolitical discourse enables them to distinguish between Jewish people as a religious entity and as a political entity; as one boy articulated, 'Zionist is the worst, however, not every Jew is a Zionist. A Zionist is the one who colonized my land. Jewish people believe in Judaism and the Israeli people who are living in Israel.' Rajaram 
(2004) notes that national identity depiction is not predetermined in place, political ideology or time and therefore nuances present themselves, thus enabling participants to further complicate the identities of Jewish people, Israelis, Zionists and their location. As one female participant stated, 'There are Jewish people in Morocco and there are Jewish people in Saudi Arabia and other Arabic countries.' Other depictions by participants were not associated with particular locations; hence these nuances did not eliminate the prevalent elements of the oppressor other. The political identity of the oppressor other was associated with acts of aggression. Military, economical and sociopsychological oppressive forms were predominant in the description of the oppressor other. Reality for the children included their experiences of the oppressor in military Israeli uniform. Also, the fact that the children knew that it was mandatory for young Israeli men to serve in the army strengthened the notion of Israel's role in being the oppressor; as one male participant stated, 'Almost all the Israelis are soldiers and are from different countries. You find one from Netherlands, and he will tell you he came here because he was forced.' The children also perceived an integration of roles between Israeli soldiers and non-military Israeli citizens. One male stated, 'An Israeli settler will shoot us or any Jew will shoot us. He does not need to wear an army uniform to start shooting on us.' Hence, participants saw a relationship between the oppressor other and their own well-being.

Sociopsychological oppression was a daily occurrence. One male participant articulated his reality as follows: 'The Israelis built this gate in front of the refugee camp and if anyone wants to visit the camp, he has to pass through it. If you refuse, they will kill you. They invaded the camp and my home.'

Palestinian children's social and psychological oppression was associated with economic hardship and community welfare. Road blocks, high unemployment and limitation of movement and commerce lead to an increase in the number of children working. One interviewee from Bethlehem expressed the economic reality by saying, 'They are rich, and we are poor. All of us are poor. Here, no one is rich. All of us want to be rich, but Israelis are very rich, and they do not want us to be rich.' Participant's own sense of well-being was contingent upon the construction of the other as having more privilege. Another female participant was more specific: 'Some Palestinians could not provide shelter and food for their families. This led to some children working. There is not enough income for families. Children used to work before; but since the uprising, there are more children working.' The different forms of oppression expressed by the children stemmed from their experiences of contemporary geopolitical events and historical development. This oppressor other category crystallized the historical experiences and global politics that were carried through to the participants' reality (Said, 1993). Children's awareness of generational narratives describing displacement and its impact contributed to their knowledge of the present and the past. Time is defined not just by the present situation, but also through past experiences that have 
shaped the present. The oppressor other was constructed within specific aggressive endeavors that were associated with the military, collective integrity and prosperity.

\section{The scattered other}

The scattered other subtheme of Palestinian national identity refers to the historical image of the Jewish people across time. The perspective of the scattered other was in relation to the Palestinian land. The narratives describe how the others were rejected by different nation-states; this indicates that there is some awareness of global geopolitics. Tuathail (2000) states that national identity is no longer constructed by the local geopolitics but it is relative to global discourses. The rejection of the Jewish people in Europe resulted in a situation in which the Palestinians were forced to accept the contemporary other (Khalidi, 1997). Children understood that the rejection of the other by different nations across time was a factor in the establishment of the state of Israel. However, participants challenged the idea of religion as a justification for immigrating to Palestine. As one male participant stated, 'Some converted to Judaism before they came, but the moment they arrive they become Jews.'

Although participants acknowledged that Israel was established due to the Jewish immigration, they recognized that there were Jewish communities living in Palestine before the establishment of the state of Israel as part of the Jewish scattered community. One male participant said, 'There were Jews living here before the Palestinian displacement; they were against the idea that Palestine is their land. They were Jew[ish] people not Israelis.' Tuathail and Dalby (1998) notes that competing geopolitical discourses are instilled in contemporary national identity and, as awareness of them increases, the meaning of territorial space becomes more uncertain. Questioning the politicization of Judaism enables the participants to problematize the notion of Jewish people as a nation. Children provided historical knowledge about different locations of the scattered other that impacts the meaning of this category.

The scattered other reflects that the Jewish people are not monolithic in ethnicity and this awareness extends the discussion to the issue of language diversity. It was necessary for the Israeli state to rejuvenate the Hebrew language in order to create a common culture. Anderson (1991) states that language has a significant role in creating a unity among the imaginary community; however, the Hebrew language was challenged, as one female participant articulated, 'Most of the Israelis are not Jews. They claim that they are Jews so they will find a state. They do not have a language. Their language is mixed from Arabic.' The scattered other adds a new dimension to this category in terms of being a victim, rejected and diverse. This knowledge conflicts with the images of the oppressor other category but simultaneously highlights the global discourse. 


\section{The religious other}

Religion is another dimension in defining the other. Participants not only discuss Judaism as a religion but also its politicization, which intersects with the construction of the other. The paradox is in understanding the complication of the other's religion. The narratives articulated religions in association with Judaism, Islam and Christianity. Participants recognize that every group has a specific faith, and all are respected by Islam, but argue the geopolitical dimension. As one female participant stated, 'The Jewish people believe in the Torah, and we fight them even if the Koran acknowledges [them] because they believe that this is their land and they want to control everything.' Judaism as a religion was never questioned by the participants, not only because it is acknowledged in the Holy Koran but also because historically it has had a presence in Palestine. However, participants' experiences of Judaism are equated with politics and its relationship to the establishment of Israel. Explaining his understanding of this issue, one boy said:

Jews think that Palestine is for them, and their grandfathers were here and should come back to it. Their grandfathers are Moses and Jesus. Moses was a Jew[ish] leader, and he was asked to go to Palestine; therefore, in these days if their grandfathers were here a long time ago, they want to come also. The new Judaism is not like the old one. Now they are fighting Christianity and Islam, but the Jewish people that are mentioned in the Koran are simply people, not the enemy of the Christians or the Muslim people. Judaism is a religion, but they converted it to a state.

Participants demonstrate their understanding that the politicization of Judaism was a factor used to create the state of Israel and they identify the political argument of Israel, supporting their view with emphasis on the fact that, as one participant stated, 'Not every Israeli is a Jew.' This knowledge stemmed from participants who had relatives or knew other Palestinians living in Israel. Participants also challenged current immigration to Israel on the basis of religion, voicing their realization that people converted to Judaism in order to seek a better life. One interviewee pointed out the following, 'I know someone who lives in Kreat 4 [a Jewish settlement in the West Bank]. They taught him Judaism, but he is still not convinced; and he comes to pray in the Mosque with the Muslim people'. The subtheme of religious other was significant because it complicated the meaning of the other. The religious other is paradoxical because it is associated with time, history, politics and place. Participants added nuances to this by articulating the religious element among the Jewish community. The religious factor is essential in the creation of a common culture, especially for a scattered community and, as Anderson (1991) states, religion enhances the shared experience among community.

\section{The allying other}

This subtheme represents the paradoxes that Palestinian children negotiate while rendering national identity. The allying other is characterized by conditions in which the other is not alienated from the self but rather is affirmed 
and integrated as a positive dimension. The Palestinian participants found several possibilities for this. One male participant made a comparison between Zionism and the allying other when he stated, 'Zionism is occupation, but an Israeli could be a person who is not interested in Zionism.' Another female interviewee explained the notion in global terms, 'Jews who are not living here and they're saying this is not our land. These groups are not settlers, and they are living overseas. They do not mix with the Israelis that are killers and terrorists.'

A prerequisite for the allying other is the acceptance of the Palestinian society, as noted by a female subject, 'He [an Israeli] should believe in God the Great and ask for forgiveness for all the things he has done against the Palestinians.' Setting up provisions to accept the allying other was articulated in relation to historical experiences. As one female participant stated, 'If a Jew is not hurting me, I will not fight him. But they took our land.' Participants differentiate between the allying other - Jewish people living in the West Bank under Palestinian nationality as well as the Jewish people who protested the Israeli occupation in the West Bank - and the remaining categories of other. One male participant stated, 'The Jews are not the ones who are occupying our land, and they do not kill us. Like on the day of the Oriental House in [East] Jerusalem when they came and defended us against the Zionists who were carrying weapons.' One female interviewee from Nablus described the Samarian (Jews who have lived in the West Bank as members of the Palestinian community) as part of the allying other, stating, 'Some of them [Samarians] have public baths, and sometimes they do witchcraft. People go there to buy Hajab [a kind of witchcraft] from them. Some of them are Palestinians and do good things to the Palestinians.'

The notion of the allying other is conditional upon acceptance of the other on the basis of religious and political agendas that endorse the Palestinians' rights. The allying other results from competing contemporary geopolitical discourses of the other that impact participants and therefore thrive in Palestinian national identity. The significance of the allying other is not only that it provides fragmentation in Palestinian children's identity but also it presents an opportunity for children to challenge the contemporary meaning of other. Tuathail (2000) indicates that identity fragmentation is important in the construction of competing discourses of national identity. This subtheme prescribed the conditions and the situation in which the participants accept the other as part of the self. Some of the conditions are already placed within the children's experience; others are still forthcoming. The other category gave children the opportunity to elaborate on the complexity of the allying other. However, the narratives also present the paradoxical reality of the children.

\section{The self - the historical self}

The self is not a mirror of the other, but it complements the other in the process of constructing national identity. The self category in Palestinian children's 
national identity encompasses six subthemes: (1) the historical refugee self, (2) ennobled self, (3) traitor self, (4) religious self, (5) resistance self and (6) geographic self. These dimensions interact to create nuances of the self. Historical experiences elaborate on the self subthemes.

\section{Historical refugee self}

The construction of the historical refugee self focuses on representations of the Palestinian people before and after the establishment of Israel in 1948. Characterizations of the historical refugee self are associated with the first tribe that came from the island of Crete in ancient times. A female participant stated: 'Canaanians [Canaanites] are the people who lived in Palestine a long time ago.' However, the children also acknowledge that Palestine is a holy place for all religions and that it is historically significant. As one male participant commented: 'It is a holy land. The land has surpassed every historical arena.' Besides being able to demonstrate historical knowledge, the children were able to describe Palestinian life before the establishment of Israel. 'They had homes; it was a tent in Filogia [Palestinian village destroyed in 1948]. Filogia was near Haifa, Jaffa, Besian. [They lived in] Tents not because they were refugees but [because] they were proud of it. They were made from the animal skins.'

Participants describe the generosity of the Palestinian people and how Palestinians, prior to displacement, offered immigrant Jews land and homes. This aspect of generosity is not only a discussion point among the Palestinian community but participants access such information from the Israeli media. One female participant pointed this out: 'On the Israeli channel, an Israeli said, "When I came to Palestine, I was given accommodation in a Palestinian house; he gave me a house near his." Participants emphasize this image, especially when talking about the self experience of a becoming a refugee. One female participant related: 'When we had the Nakbah [Palestinian displacement] in 1948, Jews invaded their [Palestinian] towns and kicked them out of their houses and killed people like in the Dir Yasian massacre.' Representations of the past are factors in creating community images that enhance unity and continuity (Anderson, 1991). These representations changed from a prosperous reality to an oppressive one in the Palestinian memory. The continual reality of oppression as presented in the refugee experience is prevalent in children's contemporary life. There are refugee camps in the West Bank, where 40 percent are refugees, and in the Gaza Strip, where 70 percent are refugees (Khalidi, 1997). A male participant said, 'Some refugees are living in villages and cities, and others in diaspora refugee camps.' However, another refugee child pointed out that even if one changed locations, one's identity would not change; therefore territorial space is not contingent on national identity (Rajaram, 2004). The construction of refugee identity is a cross-generational discourse, as pointed out by one male participant, who explained, 'My grandmother and father were evacuated from their 
village and, therefore, I am a refugee.' The notion of being a refugee was not framed in the experience of 1948. The current demolition of homes and the continuing oppression lead to assumptions that the refugee experience is continuous. Speaking to this reality, one male participant said, 'Refugees are displaced, and there is a possibility that they will be displaced again.' The refugee representation is associated with humiliation and poverty. Relying on UN food donations was the first image that came to the mind for one female subject: 'The Palestinians who are living in a refugee camp are humiliated. All day they are standing in line to get one kilogram of flour.' The refugee self is constructed out of the political knowledge that the participants acquired personally or through others who were refugees. The refugee self provides a shared experience that the Palestinian people identify with as a whole. This focal experience in history adds a contemporary edge to the national identity (Crane, 1996; Khalidi, 1997).

\section{The ennobled self}

The ennobled self is defined in terms of reasons for being proud of being Palestinian. It intersects with historical, cultural and religious aspects. It is not limited to historical time, but is linked more to timeless acts of nobility. One of the prevalent themes in the ennobled self relates to the pre-1948 displacement and the feeling of belonging to Palestine. A female participant said, 'The land is a mother to the people and, therefore, it is one's mother.' Participants mention being proud of being a Palestinian because of knowing their traditions. One male participant described his thoughts this way: 'One knows one's homeland traditions and customs; therefore, we are Palestinians.' Also self-determination was an aspect of being a proud Palestinian as voiced by another boy who said, '[A] Palestinian is the one who stayed in his land and he never left and would not give it up.' Another spin on the ennobling concept is an individual's ability to find virtue in having national roots. 'My family is in Palestine, and my community is in Palestine. I feel I belong to Palestine, and I feel I have something in Palestine', reasoned one female participant.

The ennobled self is also associated with language, religion and common cultural experiences. 'My language is an indicator of my identity.... Home is also an indicator of being a Palestinian. I have an Arab house; you will see a Koran. All Palestinians have the same problem like me', said one female interviewee. Providing shared meaning in belonging, practice and history enforces continuity of the community (Anderson, 1991). Hence, fragmentation in tradition is recognized as an opportunity; as one female participant stated, 'Palestine has a lot of people who pray and some who fast and some who do not fast.'

Pride in being a Palestinian because of the people's commitment to community and the notion of caring for each other is also a component of the ennobled self. As a male participant articulated, 'All the Palestinians are 
good; if you go and buy vegetables, the guy will give it to you cheap.' However, this pride tends to be exclusively related to the land and liberation. A male participant expressed this idea saying, 'The good Palestinian is the one who fights for an independent state.' A proud Palestinian means that they are not the oppressors. Echoing this belief, one female participant stated, 'We are not [an] enemy.'

However, participants articulated the ennobling self in hopeful terms: hope to live and continue surviving despite the political and cultural challenges they face. One female spoke of hope in these terms, 'What I like the most is hope. We are killed, but we are still resisting. If we were other people we would not have hope.' The ennobled self primarily embodies the different reasons why participants are proud of being Palestinian. The children acknowledge that the ennobled self coincided with time. The ennobled self provides reasons for enforcing the unity of Palestinian national identity.

\section{The traitor self}

Traitor is a broad concept and it is inherent to the fragmented self; fragmentation is more prevalent in contemporary identity (Tuathail, 2000). The fragmentation of self serves in contrasting the self within the geopolitical reality. The initiative of such a concept can be traced to the colonial period when locals in Palestine were required to educate the colonists about the country. This interaction of educating the Israeli Intelligence is seen as a betrayal of one's community on two dimensions: first, the traitor is not supporting the resistance or the community legacy, and second, the traitor is betraying his or her cultural tradition of survival. For Palestinians, it is important for the community to survive and for its members to continue as faithful citizens. Therefore, the challenge is in how to balance survival in the Palestinian community without betraying your people. A male participant stated, 'There were a lot of people who became Israelis. [A man I knew] he gave up being a Muslim and became a Jew. I know someone who changed from being a Palestinian to Israeli, and now he is an Israeli soldier.'

However, the dominant image of the traitor self is of collaborators with the Israel military. One male participant stated, 'The bad Palestinians first of all are the collaborators. When someone spies against his homeland, he is not a good Palestinian.' Some participants view the traitors as having no choice. 'They [the Israelis] gave them money to become collaborators. The collaborators are Palestinians but were kidnapped by the Israelis and they became Israelis', claimed one male interviewee. A female participant elaborated on the goals of the traitor self by saying, 'In order to decrease the Palestinian population and occupy the land, they used collaborators against Palestinians.'

The traitor self is the category of the Palestinian self that questions the coherence of one's national identity and the meaning of collectiveness but simultaneously creates fragmentation of the self (Tuathail, 2000). It expresses 
the dilemma of the people in political oppression. The traitor self is a rejected self that is not tolerated by the other members of the society. However, it is not only associated with spying but also with Palestinians who do not actively support the cause.

\section{The religious self}

The construction of the religious self defines the significant relationship between religion and the Palestinian people. However, the religious self is not associated with one religious faith. It is diverse and includes the world's three major religions: Islam, Christianity and Judaism. One insightful male participant observed, 'The prophet Muhammad invited all the prophets and he prayed. For no other reason than this should we defend Palestine.' One female participant stated, 'Palestine is the centre of all religions.' Another added a historical dimension, stating, 'There is the Dome of the Rock. It is God's house. Also we have Bethlehem where Jesus was born.' The participants express religion in terms of its history and its artifacts. However, Judaism is defined according to Islam but problematized when relating it to the political reality. Religion provides a shared meaning (Anderson, 1991) of the self, yet it is associated with diverse entities; this enhances the perception that Palestinians are diverse in beliefs but united within the cause.

\section{The resistance self}

The resistance self is another dimension in the children's construction of a Palestinian national identity. It demonstrates the assertiveness of the Palestinian people to be free across time. It also shows the children's abilities to articulate reasons for and tools of resistance. The resistance self is concerned with the Palestinians' ability to resist occupation since 1948 and the different strategies associated with such activities. The resistance self is not exclusive to a time or age. Children articulate resistance activities of past generations, expressing that the continuous resistance is due to the continuous oppression. One male participant stated it this way: 'He [grandfather] told me that there were a lot of revolutionaries, but the Jews were stronger and the revolutionaries could not defeat them. But we might have a generation that could defend their land and liberate it.'

The complexity of the representation of the resistance self is in its relationship to life, prosperity and poverty. The contemporary geopolitical discourse is infused in these depictions of national identity (Khalidi, 1997) and children's perceptions of the political situation. 'I will be a martyr and I go to heaven and I will go to God and in this way I defended my homeland. In heaven there are vegetables and food', explained one male participant. Some of the children, however, articulated that the Palestinian people should avoid dying while resisting Israeli occupation. This discussion is in reference to the military power of Israel and the use of weapons. One male participant pointed out, 'Not everyone should die. People should think about getting 
weapons in order to defend our homeland. The Jews are stronger than us.' The understanding that resistance obstructs the expansion of Israeli control of the Palestinian people is another element of the resistance self.

Contextualizing resistance is present in the children's voices; this emerges as children experience oppression and the helplessness of Palestinian people. As a female participant stated, 'The other day at the Damascus Gate, they threw tear gas. Everything went up and down. They want us to give up and to get out of the land.' Memories of helplessness against Israeli oppression are not restricted to adult images. Participants recalled events in which children were killed without any reason, thereby, justifying resistance. In the 2000 uprising, the child Mohamed Al-Dora was the killed by the Israeli military near a Gaza checkpoint while his father was holding on to him. One female interviewee commented on this event, saying, 'At the beginning of the uprising, Mohamed Al-Dora, the way they killed him, it was horrible. When people saw it on TV, they were shocked and deeply affected. They killed him and killed the Palestinian people with him thousands [of] times over.' Children's ability to synthesize such political complexity indicates that their experience is part of national continuance and national survival. This is in accordance with the Anderson (1991) notion of the continuity of a nation. The contemporary meaning of resistance represents a factor that creates a nuance for future national identity that is conditioned by geopolitical discourse (Pappe, 1992).

\section{The geographic self}

The geographic self is significant because it defines who is a Palestinian and determines whether location, time and citizenship exclusively define a person's national identity. Distinguishing between citizenship, nationality and roots is purposeful in the articulation of the meaning of being a Palestinian. These contemporary themes are the results of the contested meaning of territorial space and national identity (Rajaram, 2004; Tuathail and Dalby, 1998). Children delicately differentiate who is a Palestinian after the 1948 displacement. The two dimensions in the geographic self are one's birthplace and one's roots. Defining the geographic self is a statement of culture, history and family. However, the children also mentioned the geographic self associated with a map. The map concept was utilized to address the views of the Palestinian geographical situations in the West Bank, Israel, the diaspora and the Gaza Strip. Therefore, the geographic self is divided into four categories: the West Bank self, the Gaza self, the Palestinians of ' 48 self and the diaspora self. These categories are in accordance with the locations in which the Palestinian people currently live. Additionally, the interviewees articulated a definition of the geographic self that enhances the understanding of a Jewish dimension. It is noteworthy that roots do not relate to the contemporary people; they refer to the first people (Canaanites) who inhabited the land. However, the definition of the territory of Palestine was recognized by its 
pre-Second World War boundaries, before Britain and France divided and renamed the region from the Arab region to the Middle East and from Syria, Lebanon, Jordan and Palestine being one country under Great Syria to small entities (Pappe, 1992). A young female participant defined Palestine as follows: 'It is part of Great Syria and is in Asia, and it has people and we are the indigenous people.' However, participants insisted that the natural borders of Palestine are different from the political ones. As a male interviewee stated, 'The political map was imposed by Israel: there was Lebanon in the north, and Palestine had been part of Jordan, but they [Israel] put a line between us.' The children understand that the Israeli policy of creating maps destroyed kinship among Palestinians, as a female participant said:

\footnotetext{
Now Palestine is small states. If you do not have the right ID, you cannot pass. If you are from this area, you should stay in your area and cannot cross to other area in the West Bank. And now the Israeli government calls the Arabs in Israel 'ArabIsraelis,' but we call them Arabs of '48. Long time ago all of it was Palestine, and Israel took part of it. Tel-Aviv used to be called Tel El-Rabig.
}

The definition of location and its relationship to official documentation is challenged by the interviewees because they believe that citizenship does not indicate roots and nationality. This notion is related to geopolitical discourse (Tuathail and Dalby, 1998). Roots define the origins and cultures of people, but a document does not provide loyalty or belongingness to a particular nation-state. 'There are some people in the refugee camp that have Israeli IDs, but they are Palestinian. The question is where you were born, what your original town is, where you belong, and what you love', voiced one female participant. Anderson (1991) indicates that culture is the substantial element in the context of national identity. Expressing this thought, one male said: 'Palestinians are; their roots are Palestinian. Their families are Palestinian, and their grandfathers are Palestinians. The children continue to be Palestinians even if they went to other countries.'

Nevertheless, participants are specific in the allocation of people to place and therefore nationality is conditional upon geopolitical discourse (Tuathail, 2000). The West Bank and the Gaza Strip comprised one category of geographic self. The reason for combining the West Bank and the Gaza Strip in the geographic self was that the participants think of them both in relation to Israel. One male interviewee said, 'Now Palestine has been divided, but it is occupied by Israel and the rest of the land is called Israel.' Defining Palestinians by location is contested, especially when discussing Palestinians living in Israel. The formal term used by the Israeli state is ArabIsraelis; however, the participants used an alternative name, the Palestinians of' 48 - ' 48 indicating the year in which Israel was established and when, as a result, 70 percent of the Palestinians living in what is now Israel were displaced (Pappe, 1992). This term - Palestinians of ' 48 - denotes time, location and identity. Hence, the participants' perception of the Palestinians of ' 48 self was controversial. A female participant's opinion was that: 'They are Palestinian, 
but they are not living well because they are under the authority of Israel, and they [the Israelis] trouble them and they kill their children.' A male participant viewed them in a different manner, saying, 'They are Palestinians, and they held onto the land and they refused to leave.' Knowing the term Palestinians of ' 48 is based on political history and a formal document, a male participant stated, 'I am talking about the bad ' 48 Palestinians, the ones who assimilate with Jewish culture and collaborate with them.'

Participants' articulation of being Palestinian is not limited to those living in a particular space but encompasses elements of culture and common experience. This was the case in the construction of the Diasporic self category of the geographic self, which included Palestinians who lived outside historical Palestine and since the 1948 displacement experience. The Diasporic self ranged from being a refugee in Jordan or a resident in a western country. A male participant recalled: 'On a TV talk show, a Palestinian from Germany called. He lives in Germany, but he is still a Palestinian and his children are the same.' The children's geographic self was not only based on their contemporary perception of maps and borders, but it was also based on the traditional meaning of roots, rituals and belonging to the land. The participants acknowledged the manipulation of the pre-1920s borders and the creation of the Middle East borders. However, the children found the post1948 borders to be controversial. This was evident in their construction of the various dimensions of the geographic self. The shape of the West Bank self and Gaza geographic self, the Palestinians of ' 48 self and the Diasporic self add to the historical geopolitical discourse expressed by the participants. The narratives present multiple images of the self and location that intertwine with the construction of the other. The challenge is whether all Palestinians in different locations would be portrayed in the same way and whether the responses are related to the same other.

\section{Conclusion}

This research is an examination of Palestinian children's construction of a contemporary Palestinian national identity that intertwines with the image of the other and self; and provides nuances in the making. The other is constructed on the remnants of colonization (Said, 1993), while the self includes elements of ethnocentricity that are contingent upon the creation of the other. Production of national identity is fragmented in nature for both the other and the self categories. Even though the fragmentation was juxtaposed, the self did not mirror the other, rather it complicates the images that intersect in history, geopolitical discourses, economy and community narratives. The fragmentation placed in the allying other provides possibilities to connect with the other without insecurity and establishes possibilities for 'ecopolitics' (Dalby, 1998: 308). The 'ecopolitics' eliminates the tension associated with sovereignty, geopolitical discourse and territories. The paradox is that the 
contemporary notion of national identity echoes the fragmented relationship of the meaning of territories (Tuathail and Dalby, 1998). The historical development of the Palestinian people aids in the production of a particular knowledge that is in line with a collective conscious and geopolitical reality. The Palestinian children of 1948 are the grandfathers of present-day Palestinian children. Therefore, children's capacity to construct an identity is associated with the familiarity of past generations' experiences and with their ability to connect to the global geopolitical discourse that affects the local milieu. Palestinian children's national identity is not static but encourages them to relate generational conscious experiences with the contemporary political situation. In addition, narratives were not only passed down from family members but were accessed from media and political discourse. Palestinian children's national identity infuses nuances in their geopolitical agency and therefore mirrors the complexity of Palestinian children. Their agency not only articulates the traumatized implication of oppression on children but enhances our understanding of relating children's rendering of national identity and geopolitical discourses. Palestinian children's geopolitical agency of national identity encompasses trauma, historical political experience and collective consciousness as well as their reflections on the contemporary political reality.

\section{References}

Abu-Lughod, I. (1993) Challenges of Palestinian Education. West Bank, Nablus: Center for Palestine Research and Studies. (In Arabic.)

Anderson, B. (1991) Imagined Communities: Reflections on the Origin and Spread of Nationalism. London: Verso.

Aqtash, N.A. (2005) 'Palestinian National Authority's Public Relations Policies Relating to Israel: Current Attitudes among Palestinian Officials and Media Experts', Public Relations Review 31: 376-80.

Assad, I. (2000) 'Palestinian Educational Philosophy between Past and Present', Studies in Philosophy and Education 19: 387-403.

Bixler, M. (2005) The Lost Boys of Sudan: An American Story of the Refugee Experience. London: The University of Georgia Press.

Carey, R. (ed.) (2001) The New Intifada Resisting Israel's Apartheid. New York: Verso.

Cheney, K. (2005) ' "Our Children Have Only Known War”: Children's Experiences and the Uses of Childhood in Northern Uganda', Children's Geographies 3(1): 23-45.

Crane, S.A. (1996) '(Not) Writing History: Rethinking the Intersections of Personal History and Collective Memory with Hans Von Aufsess', History and Memory 8(1): 5-25.

Dalby, S. (1998) 'Geopoltics and Global Security: Culture, Identity and the "Pogo" Syndrome', in G. Tuathail and S. Dalby (eds), Rethinking Geopolitics, pp. 295-313. New York: Routledge.

Feerick, M.M. and R. Prinz (2003) 'Children Exposed to Community Violence of War/ Terrorism: Current Status and Research Directions - Introduction', Clinical Child and Family Psychology Review 6: 221-2.

Habashi, J. (2004) The Political Socialization of Palestinian Children: Children as Geopolitical Agents, published doctoral dissertation. Kent, $\mathrm{OH}$ : Kent State University.

Howard, S. and J. Gill (2001) “ "It's Like We're Normal Way and Everyone Else is Different": Australian Children's Constructions of Citizenship and National Identity', Educational Studies 27: 87-103. 
Hutton, P.H. (1993) History as an Art of Memory. London: University Press of New England.

Jennings, K.M. (1996) 'Political Knowledge Over Time and Across Generations', Public Opinion Quarterly 60: 228-52.

Kapitan, T. (1997) Philosophical Perspectives on the Israeli-Palestinian Conflict. Armonk, NY: M.E. Sharpe.

Kelman, H. (1999) 'The Interdependence of Israeli and Palestinian National Identities: The Role of the Other in Existential Conflicts', Journal of Social Issues 55: 581-600.

Khalidi, R. (1997) Palestinian Identity: The Construction of Modern National Consciousness. New York: Columbia University Press.

Link, P.S. (ed.) (1996) Middle East Imbroglio: Status and Prospects. New York: Nova Science.

Myers, K. (1999) 'National Identity, Citizenship and Education for Displacement: Spanish Refugee Children in Cambridge, 1937', History of Education 28: 313-25.

Pappe, I. (1992) The Making of the Arab-Israeli Conflict 1947-51. New York: Tauris.

Rajaram, P. (2004) 'Disruptive Writing and a Critique of Territoriality', Review of International Studies 30(2).

Said, E. (1993) Culture and Imperialism. New York: Knopf

Smith, A. (1991) National Identity. London: University of Nevada Press.

Smith, C.D. (2001) Palestine and the Arab-Israeli Conflict. Boston, MA: St Martin's Press.

Tuathail, G. (2000) 'The Postmodern Geopolitical Conditions: States, Statecraft, and Security at the Millennium', Annals of the Association of American Geographers 90(1): 166-78.

Tuathail, G. and S. Dalby (1998) 'Introduction: Rethinking Geopolitics: Toward a Critical Geopolitics', in G. Tuathail and S. Dalby (ed.) Rethinking Geopolitics, pp. 1-15. New York: Routledge. 